\title{
Plasma Fibrinogen and Fibrin Degradation Product (FDP) in Preeclampsia
}

\author{
Sharmin Sultana *1, Susmita Nargis ${ }^{2}$, Heera Lal Roy ${ }^{3}$, Qazi Shamima Akhter ${ }^{4}$, Rukhsana Afroz ${ }^{5}$
}

\begin{abstract}
Introduction: Hypercoagulable state is seen in preeclampsia which acts as a risk factor for thromboembolism \& DIC. Altered coagulation indices (serum Fibrinogen \& FDP) have been reported in patients with preeclampsia and have been suggested as a sensitive marker for detection of bleeding complications. This study was carried out to compare the coagulation indices in preeclamptic women. Materials \& Methods: This cross sectional study was conducted in the Department of Physiology, Dhaka Medical College (DMC), Dhaka from January to December 2014. Total 100 women aged 18 - 40 years were selected from the department of Obstetrics \& Gynaecology of DMCH, Dhaka for this study. Among them 50 were preeclamptic and age matched 50 healthy nonpregnant women were considered as control group. Fibrinogen \& Fibrin Degradation Product (FDP) were analyzed on automated coagulation analyzer. Result: In this study, serum Fibrinogen \& FDP were significantly higher in preeclamptic than those of healthy women. Moreover, $100 \%$ \& $64 \%$ preeclamptic patient had raised serum Fibrinogen \& FDP respectively. Conclusion: From this study it can be concluded that serum Fibrinogen \& FDP are directly related with preeclampsia.
\end{abstract}

Keywords: Preeclampsia, Plasma fibrinogen, Fibrin degradation product.

Number of Tables: 03; Number of References: 16; Number of Correspondences: 05

*1. Corresponding Author: Dr. Sharmin Sultana Assistant Professor, Department of Physiology Ad-din Sakina Medical College, Jessore. Email:sharminsultana2015@yahoo.com

\section{Dr. Susmita Nargis}

Assistant Professor, Department of Biochemistry Ad-din Sakina Medical College, Jessore.

3. Dr. Heera Lal Roy

Assistant Professor, Department of Biochemistry Khulna City Medical College, Khulna.

4. Dr. Qazi Shamima Akhter

Professor, Department of Physiology

Dhaka Medical College, Dhaka.

\section{Dr. Rukhsana Afroz}

Assistant Professor, Department of Physiology

Bikrampur Bhuiyan Medical College, Munshiganj, Dhaka.

\section{Introduction}

Preeclampsia is a pregnancy specific, idiopathic multisystem disorder characterized by the development of hypertension and proteinuria after the 20 weeks of gestation ${ }^{1,2}$. It may present itself as a primary disorder or may complicate pre-existing pathology like chronic hypertension or chronic nephritis ${ }^{3}$.

Preeclampsia can be categorized clinically as (1) mild preeclampsia (blood pressure $>140 / 90 \mathrm{~mm}$ $\mathrm{Hg}$ and proteinuria upto $1+$ ) and (2) severe preeclampsia (blood pressure $>160 / 110 \mathrm{~mm} \mathrm{Hg}$ with proteinuria $>1+)^{4}$. According to the time of onset, preeclampsia can also be categorized as (1)early onset preeclampsia (before 34 wks gestation) and
(2) late onset preeclampsia (after $34 \mathrm{wks}$ gestation $)^{5}$.

Preeclampsia creates a functional derangement of multiple organ system. Complications of preeclampsia include eclampsia, placental abruption, ascities, hepatic infarction and rupture, intra-abdominal bleeding, pulmonary edema and acute renal failure. Twenty percent $(20 \%)$ of women with severe preeclampsia develops HELLP syndrome (hemolysis, elevated liver enzymes, low platelets) and the same percentage (20\%) among HELLP syndrome develops disseminated intravascular coagulation (DIC). Complications affecting the developing fetus include intrauterine growth retardation, prematurity, oligohydramnios, bronchopulmonary dysplasia and increased risk of perinatal death ${ }^{2}$. During normal pregnancy profound changes occur in the coagulation and fibrinolytic system of the mother causing a hypercoagulable state. In preeclampsia there is a distinct possibility of accentuation of this hypercoagulable state of pregnancy ${ }^{4}$.

Numerous studies observed coagulation abnormalities in preeclampsia. The level of anticoagulants such as antithrombin III, protein $\mathrm{C}$ and protein $\mathrm{S}$ are decreased in these groups. The clotting factors such as factor VIII and von Willebrand factors are elevated in preeclampsia. There is also increase in plasminogen activator inhibitor type 1 (PAI-1) in preeclampsia. So preeclampsia is a highly thrombotic and procoagulant state ${ }^{1}$.

Fibrinogen is the primary blood clotting factor. Fibrin clot is formed from fibrinogen. Fibrinogen plays a vital role in the process of inflammation, atherogenesis and thrombogenesis. Fibrinogen is a cofactor in platelet activation and may directly contribute to platelet plaque 
formation. This higher serum fibrinogen level may increases the blood viscosity, platelet aggregation and causes thrombus formation ${ }^{7,8}$.

Fibrin degradation products are component of the blood produced by clot degeneration. These are produced by the action of plasmin on deposited fibrin.

An excess of FDP indicates the increased intravascular coagulation and increase in fibrinolytic activity in severe preeclampsia 9 .

Several studies showed increased serum fibrinogen and FDP in patients with severe preeclampsia9,10. But some studies found low serum fibrinogen level in severe preeclampsia $^{6,11,12}$

From the above studies, it has been observed that the result is conflicting. Several studies have done abroad to observe the fibrinogen and FDP levels in these groups but their exact relationship with preeclampsia still debatable. As, there is less published data available regarding this topic in our country, the relationship among these parameters in the Bangladeshi preeclamptic is not precisely known. Furthermore, we need a data from which we can compare these parameters in our population.

\section{Materials and Methods}

This cross sectional analytic study was conducted in the Department of Physiology, Dhaka Medical College, Dhaka, during the period from January 2014 to December 2014. Protocol of this study was approved by Ethical Review Committee of Dhaka Medical College, Dhaka. For this study, 50 diagnosed preeclamptic women aged 18 to 40 years were selected as group B.Age matched 50 healthy nonpregnant women were considered as control group (group-A) for comparison. The subjects were selected from department of Obstetrics and Gynaecology, Dhaka Medical College Hospital and from personal contact in different areas of Dhaka city by simple random sampling. After selection the nature, purpose, benefit and risks of the study were explained in details. Informed written consent was taken from the participants. Before taking blood detailed family and medical history were taken and recorded in a prefixed data schedule. Plasma fibrinogen and fibrin degradation product (FDP) were estimated on automated coagulation analyzer, Sysmex CA - 500 series.Plasma fibrinogen was estimated by using the Dade $(\mathbb{B}$ Fibrinogen determination reagent. Plasma fibrinogen was estimated by using the latex particles coated with monoclonal antibodies to FDP. In addition BMI was calculated and blood pressure was measured. Presence of proteinuria was determined by conventional heat coagulation test ${ }^{13}$. Then interpretation of the heat coagulation test was done according to presence of turbidity in the urine as nil/trace $(0), 1+, 2+, 3+$ and $4+13,14$. For statisticalanalysis one-way ANOVA test, Bonferroni test and Pearson's correlation co-efficient (r) test were performed by using SPSS version 22 .

\section{Results}

In this study, the plasma fibrinogen level was significantly $(p<0.001)$ higher in preeclampsia in comparison to control group. Again, the plasma fibrin degradation product (FDP) was significantly $(p<0.001)$ higher in preeclampsia in comparison to control group.

Table-I: General characteristics of the subjects in different groups $(n=100)$.

\begin{tabular}{lcc}
\hline Parameters & $\begin{array}{c}\text { Healthy } \\
(\mathbf{n}=\mathbf{5 0})\end{array}$ & $\begin{array}{c}\text { Ponpregnant } \\
(\mathbf{n}=\mathbf{5 0})\end{array}$ \\
\hline Age $($ years) & $28.24 \pm 4.63$ & $26.86 \pm 5.33$ \\
BMI $\left(\mathrm{kg} / \mathrm{m}^{2}\right)$ & $26.17 \pm 2.58$ & $27.72 \pm 3.5$ \\
SBP $(\mathrm{mmHg})$ & $112.2 \pm 7.1$ & $159.8 \pm 19.2^{*}$ \\
DBP $(\mathrm{mmHg})$ & $73.0 \pm 6.1$ & $110.0 \pm 9.9^{*}$ \\
Urinary protein level $(\mathrm{gm} / \mathrm{L})$ & - & $1.34 \pm 1.72^{*}$ \\
\hline
\end{tabular}

Results are expressed as Mean \pm SD. Figures in parentheses indicate range. One-way ANOVA test was performed to compare among groups. $\mathrm{n}=$ Number of subjects. ${ }^{*} \mathrm{p}<0.001$, compared to control. BMI $=$ Body mass index; $\mathrm{SBP}=$ Systolic blood pressure; $\mathrm{DBP}=$ Diastolic blood pressure.

The mean systolic $(159.8 \pm 19.2 \mathrm{mmHg})$ anddiastolic $(110.0 \pm 9.9 \mathrm{mmHg})$ blood pressure were significantly higher in preeclampsiacompared to healthy non pregnant women(SBP112.2 $\pm 7.12 \mathrm{mmHg}$, DBP $73.0 \pm 6.1 \mathrm{mmHg}$ ) difference was significant. Again, the mean urinary protein level was significantly higher $1.34 \pm 1.72 \mathrm{gm} / \mathrm{L}$ in preeclampsia compared tohealthy non pregnant women.

Table-II: Fibrinogen and FDP of the subjects in different groups $(n=50)$.

\begin{tabular}{lccc}
\hline Groups & N & Fibrinogen(mg/d) & FDP $(\boldsymbol{\mu g} / \mathbf{m l})$ \\
\hline $\mathrm{A}$ & 50 & $312.4 \pm 102.5$ & $4.85 \pm 2.64$ \\
$\mathrm{~B}_{2}$ & 50 & $665.2 \pm 99.1^{*}$ & $14.1 \pm 118^{*}$ \\
\hline
\end{tabular}

Results are expressed as Mean \pm SD. Figures in parentheses indicate range. One-way ANOVA test was performed to compare among four groups. Bonferroni test was performed to compare between groups. $\mathrm{n}=$ Number of subjects; $*$ p $<0.05$.

The mean serum fibrinogen $(665.2 \pm 99.1 \mathrm{mg} / \mathrm{dl})$ and $\operatorname{FDP}(14.1 \pm 118 \mu \mathrm{g} / \mathrm{ml})$ level were significantly higher in preeclampsia thanhealthy non pregnant women.

Table-III: Distribution of the subjects by Fibrinogen and FDP in study groups.

\begin{tabular}{|c|c|}
\hline Parameters & $\begin{array}{l}B_{2} \\
\text { n(\%) }\end{array}$ \\
\hline Fibrinogen $<400 \mathrm{mg} / \mathrm{dl}$ & $0(0.0 \%)$ \\
\hline$>400 \mathrm{mg} / \mathrm{dl}$ & $50(100 \%)$ \\
\hline $\mathrm{FDP}<5 \mu \mathrm{g} / \mathrm{ml}$ & $18(36 \%)$ \\
\hline$>5 \mu \mathrm{g} / \mathrm{ml}$ & $32(64 \%)$ \\
\hline
\end{tabular}

Results are expressed as frequency and percentage. $\mathrm{n}=$ Number of subjects

Group A : Healthy adult non pregnant women (Control group)

Group $B_{2} \quad$ : Women with preeclampsia (Study group) 
Moreover in this study, elevated plasma fibrinogen $(>400 \mathrm{mg} / \mathrm{dL})$ and plasma fibrin degradation product (FDP) $(>5 \mu \mathrm{g} / \mathrm{ml})$ were found in $100 \%$ and $64 \%$ of preeclamptic women respectively.

\section{Discussion}

In the present study, mean plasma fibrinogen level was higher inpreeclamptic women than healthy nonpregnant female.This finding was in agreement with those of different researchers of different countries ${ }^{9,10}$. But some investigators did not find significant difference of plasma fibrinogen level between preeclamptic women and healthy non pregnant female ${ }^{6,11}$.

In this study plasma fibrin degradation product (FDP) was higher in preeclamptic women than healthy non pregnant female. This result is similar to other authors ${ }^{6,9-12,15}$.

But some investigators did not find significant difference of plasma fibrin degradation product (FDP) level between preeclamptic women and healthy non pregnant female ${ }^{16}$

Literature review suggested that raised plasma fibrinogen and FDP in preeclampsia were due to the exaggerated systemic inflammatory response and fibrinolytic activity ${ }^{9}$.

In the present study, raised plasma fibrinogen and FDP in preeclampsia than control women is attributed to these facts.

\section{Conclusion}

From the result of this study, it may be concluded that increased plasma fibrinogen and FDP level may act as a future risk of developing thromboembolic disorder and disseminated intravascular coagulation in preeclampsia. Therefore, estimation of these parameters in preeclampsia may provide information for further medical care and will minimize the further complications thereby reducing both maternal and fetal mortality and morbidity.

Conflict of Interests: None.

\section{Acknowledgement}

The author's thanks to Dr. Shamima Akhter, Professor (Physiology), Dhaka Medical College, Dhaka, for her assistance in preparing this original article.

\section{References}

1. Onisai M, Vladareane AM, Bumea H. Study of the hematological picture of platelet function in preeclampsia- report of a series of cases. Med J Clin Med. 2009; 4(4): 326-37.

2. Coppage KH, Sibai BM. Preeclampsia and eclampsia. Glob. Libr. Women's med. 2008; ISSN (1756-2228): Retrieved June 19, from http://www.glowm.com/section-view/heading/Preeclampsia and Eclampsia.

3. Anjana S, Poonam M, Shradha B. Management of pregnancy induced hypertension. IJRAP. 2010; 1(2): 390-8.

4. Chauhan P, Rawat U, Bisht V. Comparison of coagulation profile in pre-eclamptic and eclamptic patients with normotensive pregnant patients. J of Evol Med and Dental Sci. 2014; 3(12): $3208-15$.

https://doi.org/10.14260/jemds/2014/2268

5. Petla LT, Chikkala R, Ratnakar KS. Biomarkers for the management of preeclampsia in pregnant women. IJMR. 2013; 138 (1): 60-7.

PMid:24056556

6. Dave R, Agravat A, Dhruva G. Comparative study if coagulation factors in preeclampsia and normal pregnancy. IJSR. 2014; 3(4): 377-8.

https://doi.org/10.15373/22778179/APR2014/135

7. Bolaman Z, Kok F, Kadikoylu G. The Changes of Coagulation Parameters and Microvascular Complications in Diabetes Mellitus. Endocrinologist. 2007; 17: 196-9.

https://doi.org/10.1097/TEN.0b013e31813435c1

8. Kafle DR, Shrestha P. Study of fibrinogen in patients with diabetes mellitus. Nepal Med Coll J. 2010; 12(1): 34-7.

PMid:20677607

9. Sogani S, Sarkar PD. Evaluation of plasma fibrinogen and plasma fibrin degradation product (FDP) in preeclampsia. J Clin Biomed Sci. 2013; 3(4): 201-3.

10. Alwan AF, Zubair AM, Salman SW. Study of plasma fibrinogen in pregnant women with severe preeclampsia. IOSR-JDMS. 2013; 8(5): 55-9.

https://doi.org/10.9790/0853-0855559

11. Jahromi BN, Rafiee SH. Coagulation factors in severe preeclampsia. IRCMJ. 2009; 11(3): 321-24.

12. Leduc L, Wheeler JM, Kirshon B. Coagulation profile in severe preeclampsia. Thrombocytopenia in pregnancy. ACOG. 1992; 79(1).

13. Dutta DC. Text Book of Obstetrics. 6th ed. Calcutta: New Central Book Agency (P) Ltd; 2008; 666p.

14. Dissanayake VHW, Morgan L. The urine protein heat coagulation test - a useful screening test for protein uria in pregnancy in developing countries: a method validation study BJOG: Int J ObstetGynaecol. 2004; 111: 491- 4.

https://doi.org/10.1111/j.1471-0528.2004.00128.x

PMid: 15104616

15. Ghazi A, Siddiq NM, Ali T. Deranged coagulation profile among obstetric patients. Pak J Surg. 2008; 24(2): 135-37.

16. Aref WM, Mazny AE, Mazny AE. Liver dysfunction and ultrasonografic findings in pregnancy induced hypertension compared to late normal pregnancy. J Am Sci. 2012; 8(8): 74-78. 